\title{
Effect of post-natal castration on sepsis mortality in rats ${ }^{1}$
}

\author{
Efeito da castração pós-natal sobre a mortalidade na sepse em ratos
}

\author{
Joel Antonio Bernhardt ${ }^{2}$, Armando José d‘'Acampora ${ }^{3}$, Ricardo Tramonte ${ }^{4}$, João Daniel May Serafim ${ }^{5}$ \\ 1. Research performed at Surgical Technique and Experimental Surgery, Federal University of Santa Catarina (UFSC), Brazil. \\ 2. MSc, Assistant Professor, University of Vale do Itajai, School of Medicine, Santa Catarina, Brazil. \\ 3. PhD, Associate Professor, Department of Surgery, UFSC, Brazil. \\ 4. PhD, Associate Professor, Department of Morphological Sciences of UFSC, Brazil. \\ 5. MD. Resident, General Surgery Program, São José Regional Hospital, Santa Catarina, Brazil.
}

\begin{abstract}
Purpose: To investigate the influence of castration in early periods of development on survival to experimental acute sepsis. Methods: Four groups of 10 (ten) Wistar rats were used. The groups were comprised of males (M), females (F), males castrated on the fourth day of life $(\mathrm{CM})$ and males castrated on the fourth day of life with testosterone replacement (CMR). Sepsis was induced by ligature and cecal perforation in adult life. Results: The analysis of death within 24 hours following sepsis induction showed greater mortality between the $\mathrm{M}$ and the CMR groups as compared to the CM and $\mathrm{F}$ $(p=0.0180)$ groups. Multiple correspondence analysis (MCA) indicates an association between the M and the CMR groups for death within 24 hours as well as a relationship between the F and the CM groups for the absence of death and death up to 24 hours following sepsis induction. Statistical analysis of the Kaplan-Meier survival curve through log-rank demonstrates a significant difference among the four groups $(\mathrm{p}=0.0055)$ and between the $\mathrm{M}$ and the $\mathrm{F}(\mathrm{p}=0.0005)$ groups. Conclusion: Data suggest a better survival to sepsis within 24 hours for the F and CM groups, the presence or absence of testosterone in early periods of post-natal life being responsible for these findings.
\end{abstract}

Key words: Sepsis. Sex Characteristics. Testosterone.

\section{RESUMO}

Objetivo: Investigar a influência da castração em períodos precoces do desenvolvimento de ratos, na sobrevida a sepse aguda experimental quando adultos, desenvolveu-se este estudo. Métodos: Utilizou-se quatro grupos de 10 ratos Wistar divididos entre machos (GM), fêmeas (GF), machos castrados no quarto dia de vida GMC) e machos castrados no quarto dia de vida com reposição de testosterona (GMCR). A sepse foi induzida por ligadura e perfuração cecal na vida adulta. Resultados: A análise do óbito até 24 horas da indução da sepse mostrou maior mortalidade entre os GM e GMCR em relação aos grupos GMC e GF ( $\mathrm{p}=0.0180)$. A análise de correspondência múltipla $(\mathrm{ACM})$ indica uma associação entre si dos GM e GMCR para o óbito em 24 horas, assim como uma relação entre si dos GF e GMC para a ausência de óbito e o óbito até 24 horas. A análise estatística da curva de sobrevida de Kaplan-Meier pelo log-rank demonstra diferença significativa entre os quatro grupos $(\mathrm{p}=0,0055)$, e entre $\mathrm{GM}$ e GF $(\mathrm{p}=0,0005)$. Conclusão: Os dados sugerem uma maior sobrevida à sepse em 24 horas dos grupos GF e GMC, e a presença ou ausência de testosterona em períodos precoces da vida pósnatal seria responsável por este achado.

Descritores: Sepse. Caracteres Sexuais. Testosterona.

\section{Introduction}

Sepsis and the systemic inflammatory response syndrome are common causes of death in ICUs ${ }^{1,2}$, and their morbilethality have not diminished in recent years. Likewise, treatment has not significantly changed and in many cases it is meant only as life support ${ }^{3,4}$. The concept that cellular or humoral immune response is more accentuated in female than in male stems from higher immune response following immunization and infection, higher titer of immunoglobulin with higher incidence of autoimmune disease ${ }^{5,6,7}$. Anatomical and functional differences in the central nervous system (CNS), determined by sexual steroids in the early stages of development, may in part explain this different response ${ }^{8-}$
${ }^{12}$. Studies in this area were initiated with Stumpf et $\mathrm{al}^{11}$ with the introduction of location methods that pinpoint brain cells which uptake and concentrate sexual steroids. The author of these studies determined the brain areas which concentrated a higher amount of estrogens. He concluded that these areas were the anatomical substrate to justify the organization and activation of different sexual behavior, as well as hormonal influence in regard to maternity, aggressiveness, feeding and modulation of several other functions including temperature control and memory. Grossman $^{13}$ demonstrated that the immune system is subjected to the influence of sexual steroids. In the same period, Besedovsky ${ }^{14}$ demonstrated for the first time the existence of a communication between the activated immune 
system and the CNS, suggesting the CNS was involved in the immune response. The evidences that the immune system and the neuroendocrine one may influence one another are the following ${ }^{15}$ :

1. Cells of the immune, endocrine and neural systems may present receptors for cytokines, hormones, neurotransmitters and neuropeptides.

2. Immune and neuroendocrine substances coexist in lymphoid, endocrine and neural tissue.

3. Endocrine and neural mediators may affect the immune system as well as immune mediators may affect endocrine and neural structures.

The interaction takes place through a humoral afferent path (cytokines) and via the peripheral nervous system (vagus nerve and sympathetic system), and afferent paths of immune system modulation by the CNS through the Hypothalamus-Pituitary-Adrenal cortex (HPA) axis, neural (sympathetic), vagal efferent, central lipopolysaccharide, adrenocorticotrophic hormone, opiods. In rats a single great peak of testosterone occurs in the latter part of gestation and goes on until the fifth day post-natal, this latter period being responsible for the masculinization and defeminization of the developing brain ${ }^{16-19}$. The phenotype of these animals may be modified with hormones, regardless of their genetic $\operatorname{sex}^{20}$. Sexual differentiation process stems from the genetic sex which determines the gonodal sex. This latter, in turn, through the action of sexual steroids, acts on embryo, neonate, pubescent and even adult life to determine the phenotype. Sexual differentiation of the brain is an example of a direct hormonal event where the presence or absence of testosterone during fetal and neonatal will determine a male or female development ${ }^{21}$. Testosterone conversion into estradiol, which takes place in the brain and is particularly active in the hypothalamus, is the key event leading to defeminization. A group of cell will be programmed in the CNS to respond in a male or female way in adult life. The final observation is that sexual differences are the product of steroids' action during the initial stages of development, pubescent and adult life. Therefore, exposition to testis secretion in early life has permanent effects on the CNS, such effects are organizational and definite, rather than transitory or reversible such as the activation effects testosterone produce in adult rats. To this date, no experimental model has been found to study the effects of testosterone withdrawal prior to the fifth day of neonatal life of male rats and its influence on the survival of these animals after being subjected to induced bacterial infection in adult life. Thus, this study intends to evaluate the effects of post-natal castration on the survival of rats subjected to experimental acute sepsis.

\section{Methods}

The experiment was conducted in the Operatory Technique and Experimental Surgery Laboratory of the Clinical Surgery Department at the Federal University of Santa Catarina. This research was approved to Ethical Animal Committee of UFSC. In the experiment, 40 albino rats $(n=40)$ of the rattus norvegicus species and Wistar stain, of both sexes and ages ranging from four days to four months were used. Rats, supplied by the Central Biolaboratory of the Federal University of Santa Catarina (UFSC), were accommodated in polyethylene cages at the animal observation room of the Laboratory of Operative Technique and Experimental Surgery of the Surgery Department of UFSC. Animals were kept under natural light conditions, respecting day and night light cycles, at appropriate temperatures, noise and humidity conditions, receiving proper food with ad libitum access to food and water throughout the experiment. Animals were redistributes in sub-groups:

\section{Subgroup GM ( $\mathrm{n}=10)$}

Adult males subjected to induced peritonitis to observe clinical outcome;

\section{Subgroup GF $(\mathrm{n}=10)$}

Adult females subjected to induced peritonitis to observe clinical outcome;

\section{Subgroup GMC $(\mathrm{n}=10)$}

Newly-born male rats castrated at the fourth day of life and given 60 days before being used in induced peritonitis and clinical observation;

\section{Subgroup GMCR $(\mathrm{n}=10)$}

Newly-born male rats castrated and receiving testosterone replacement. Were subjected to bilateral orchiectomy at the fourth day of life and received testosterone replacement from the fifth to the 11 th day and were given 60 days before used in induced peritonitis and clinical observation (Figure 1). All animals underwent general anesthesia by ethylic ether inhalation. Surgical plane of anesthesia was established by absence of reflex to noxious stimulus. Adult animals were subjected to general anesthesia induced by inhalation of ethylic ether and maintained by intramuscular injection of a solution of $3 \%$ sodic pentobarbital plus hydrochloride 2-(2.6 xylidine)-5.6dyhidro-4H-1.3-thiazine in the doses of 20 and $10 \mathrm{mg}$ per $\mathrm{Kg}$ of weight respectively. Plane of anesthesia confirmation was established by absence of reflex to noxious stimulus.

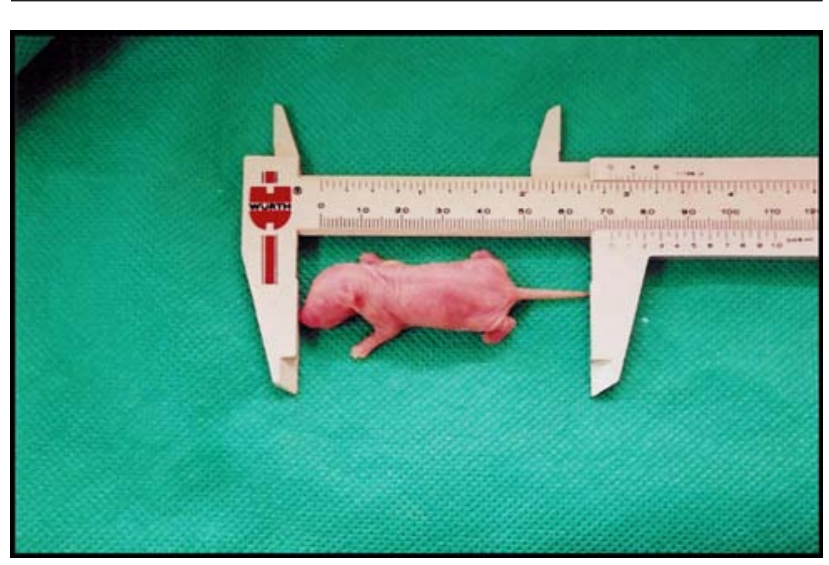

FIGURE 1 - Photograph of four day male rat 


\section{Castration}

Utilizing double-faced sticky tape, rats were immobilized in dorsal decubitus on a surgical magnifying glass with a 1 to 1.6 fold magnification. Antisepsis was carried out with $1 \%$ iodopovidone. An incision of approximately $0.3 \mathrm{~cm}$ was made on the umbilical scar transition and anus on each side. After opening of muscle and peritoneum, the testis was identified, pulled out (Figure 2 ), ligated with a 6.0 polyglactin thread and sectioned. Skin was sutured with a 6.0 polyglactin thread (Figure 3 ). Kept warm under a light bulb until recovering from anesthesia, rats were returned to the cages with their mother. They were then maintained there until the 21 day of life when they were separated from their mother and placed in cages with up to five animals per cage.

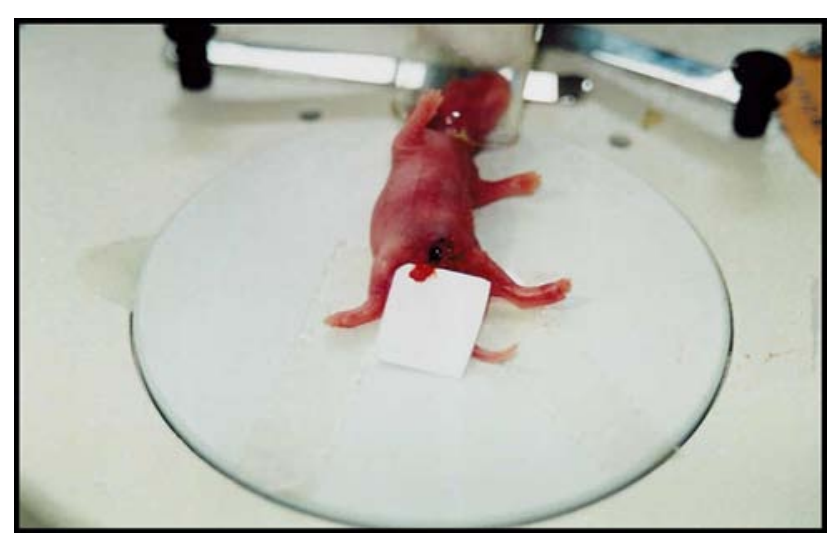

FIGURE 2 - Photograph of a male rat undergoing castration. In the detail, the exposed testes before resection.

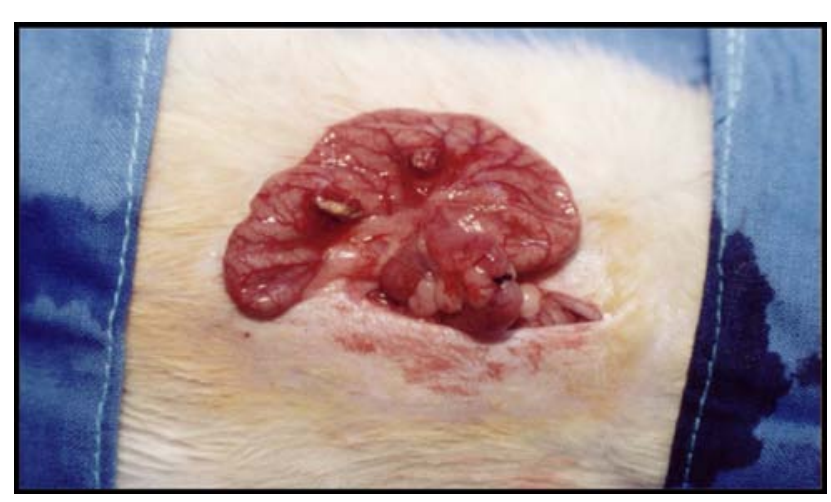

FIGURE 3 - Picture of the final aspect of the ligature showing the two cecum perforation.

\section{Testosterone replacement}

Animals in the sub-group castrated with replacement, underwent testosterone replacement after the procedure described above. Animals were weighed daily on a precision scale (Figure 4). The dose was $0.1 \mathrm{mg}$ per kilogram of body weight $(\mathrm{Kg})$ applied in an oily vehicle prepared by manipulation ${ }^{23}$. Administration was by injection in the dorsal subcutaneous tissue with an insulin injection. Replacement was carried out for seven consecutive days, at the same hour from 24 hours of castration.

\section{Experimental sepsis}

After 60 days, subgroups castrated and castrated with replacement underwent induced experimental sepsis. Subgroups males and females underwent similar sepsis at an approximate age of four months. The method used for induced sepsis was ligature and cecal perforation (LCP) as described by Wichterman et $\mathrm{al}^{24}$, and modified by d'Acampora. After, two transfixing perforations were made right under the entrance of the terminal ileum e above the entrance of the third vase in the lower part of the cecum using a $5.5 \mathrm{~mm}$ thick instrument. Loops were returned to the cavity and the abdomen was sutured in planes (peritoneum, muscle and skin) using 3.0 polypropilene with continuous suture (Figure 1-3). Animals were placed in individual number-coded boxes with data being recorded on respective tags. Animals were evaluated every one hour until their deaths to assess sepsis evidencing signals such as: hair standing on end, diminished mobility, conjunctival hemorrhage, anorexia, and loss of thirst. Time was measured in hours and minutes. After 72 hours, the occurrence of death was observed every six hours. It was considered non-death animals who stayed alive after a 10-day observation period. The moment of the last recorded death was considered to be the end of the experiment.

\section{Statistical evaluation}

Observations were structured in a database using Ms EXCEL $®($ Office 2000) and STATISTICA 6 ( (StatSoft). EPI INFO 6® was used to build Kaplan-Meier survival curve.

\section{Results}

TABLE 1 - Effect of post-natal castration on sepsis of rats. Occurrence of death in animals subjected to acute abdominal sepsis.

\begin{tabular}{lcccr}
\hline Subgroups & Deaths & Non-death & Total & \% death \\
\hline GF & 07 & 03 & 10 & $70 \%$ \\
GMC & 08 & 02 & 10 & $80 \%$ \\
GMCR & 09 & 01 & 10 & $90 \%$ \\
GM & 10 & 00 & 10 & $100 \%$ \\
\hline Total & $\mathbf{3 4}$ & $\mathbf{0 6}$ & $\mathbf{4 0}$ & $\mathbf{8 5 \%}$ \\
\hline
\end{tabular}

GF: female subgroup; GMC: castrated male subgroup; GMCR: castrated male with testosterone replacement subgroup; GM: male subgroup.

TABLE 2 - Effect of post-natal castration on sepsis mortality in rats. Percentage representation of death among animals subjected to acute abdominal sepsis within 24 hours.

\begin{tabular}{lccl}
\hline Subgroups & $\begin{array}{c}\text { Death within } \\
\text { 24 hours }\end{array}$ & \% & Qui-Square \\
\hline GF & 3 & $11.54 \%$ & 0.072 \\
GMC & 5 & $19.23 \%$ & 0.013 \\
GMCR & 8 & $30.77 \%$ & 0.013 \\
GM & 10 & $38.46 \%$ & 0.072 \\
\hline Total & $\mathbf{2 6}$ & $\mathbf{1 0 0 \%}$ & $\mathbf{0 . 1 7 1 5 9 8}$ \\
\hline
\end{tabular}

GF: female subgroup; GMC: castrated male subgroup; GMCR: castrated male with testosterone replacement subgroup; GM: male subgroup. $* \mathbf{p}=\mathbf{0 . 0 1 8 0}$ 


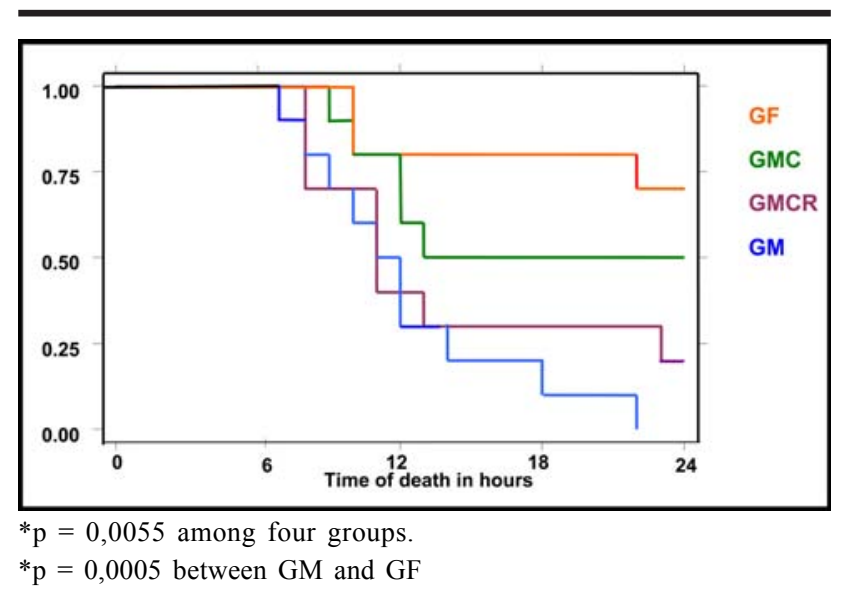

FIGURE 4 - Kaplan-Meier survival curve for death within 24 hours.

\section{Discussion}

Sepsis still poses a great challenge for clinicians and surgeons alike. In the United States, it is estimated that 400.000 cases of sepsis occur each year, half of which leading to septic shock and a quarter leading to death ${ }^{22}$. It is necessary to intensively look for new alternatives to study the physiopathology and therapeutical options for this condition. Thus, experimental studies, using several animal species still provide the best option for the research and creation of new investigation methods that may later be applied in pre-clinical trials ${ }^{23}$. One of the peritonitis models commonly used in the experimental research of sepsis was devised by Wichterman et $\mathrm{al}^{24}$. It consists of mechanically obstructing the cecum with an anabsorving thread placed distally to the ileum-cecal valve with its later perforation. d'Acampora ${ }^{25}$ devised a modification to this model, applying the ligature to the end of the cecum rather than to the ileum terminus. He also noticed that if no mucus eversion occurs the model won't work since there will be a local obstruction that is fairly immediate. This model is known as the Cecal Ligature and Perforation (CLP), where the advantage lies in the simplicity of the execution and its easy reproduction. In addition, it is a model where the contamination occurs in the peritoneum, whose flora is mixed, making it more similar to abdominal infection problems experienced by humans, such as appendicitis and diverticulitis. In the literature review on the subject, the multifaceted aspects of sepsis variables was made clear with clinical and epidemiological studies demonstrating the difference in response to the condition, especially in regard to mortality rates, when comparing male and female infection processes. In our midst, d'Acampora ${ }^{3}$ had already noticed, in experimental rat sepsis studies, a higher and faster death rate among males compared to females - the latter apparently resisting better to peritonitis and ensuing sepsis. In the same line, Oberholzer et $\mathrm{al}^{26}$ after evaluating 1276 polytraumatized patients, found significant difference in the incidence of post-trauma sepsis, as well as multiple organ dysfunction syndrome, with male patients more likely to be affected. Schroder et $\mathrm{al}^{10}$ in a prospective study with $52 \mathrm{ICU}$ patients - homogeneous in regard age, origin and severity of sepsis - found a $70 \%$ mortality among men against $26 \%$ among women. In one other study, Yesilova et $\mathrm{al}^{27}$ evaluated patients with idiopathic hypogonadotrophic hypogonadism and compared immunity parameters before and after gonodotrophin replacement and concluded that the absence of testosterone results in an increase of cellular and humoral immunity. These facts reveled by the utilized literature, lead to the present study which compared the responses of a group of adult male rats, adult female rats, male rats castrated on the fourth day of life and male rats castrated on the four day of life receiving hormone replacement from the fifth to the $11^{\text {th }}$ day of life. Newly-born and castrated rats were allowed to reach an adult age prior to undergo CLP induced peritonitis - carried out on the same day for all rats and by the same researcher - and were observed until their deaths. Because Yesilova et $\mathrm{a}^{35}$ states that the absence of testosterone increases cellular and humoral immunity, the expectation was to observe death in a decreasing order in the subgroups males (GM), castrated males with replacement (GMCR), castrated males (GMC) and females (GF). Global mortality observed in the experiment was $85 \%$. This rate was considered satisfactory, since the intention was to study acute sepsis. Death rates per subgroup were progressive among subgroups GF, GMC, GMCR and GM, with $70,80,90$ and $100 \%$ respectively. Statistical analysis did not show significant diference in this period, in spite of this data trend. When compared isolatedly subgroups GF and GM, we obtained $p=0.0637$. This may suggest that if the sample in the experiment were bigger, maybe there would be a significant relation in the obtained results (Tables 1 and 3). When only the deaths that occurred within 24 hours are evaluated, the number of 16 animals corresponds to $65 \%$ of the total animals in the experiment and $76 \%$ of all animals who died (Table 2). In the comparative evaluation among the subgroups, there was a progression in the death rates, with the following percentage per group: GF $11,54 \%$, GMC 19,23\%, GMCR 30,77\% and GM 38,46\%. Statistical analysis demonstrates significance in the Kruskal-Wallis test, with $\mathrm{p}=0,0180$. These differences among groups, associated with the proximity of GF and GMC - no testosterone action - suggest the action of this hormone in the inhibition of the immune response in these animals (Table 2). Likewise, GM and GMCR groups - animals who had a permanent (GM) or temporary (GMCR) testosterone activity - may indicate that the action of testosterone inhibits the immune response to experimental acute sepsis. This action would take place in the early stages of life, since animals who underwent hormonal manipulation in these critical stages responded differently in their adult life. Analyzing the hormonal state of these animals, we have the following situations:

GF: adult females with no hormone manipulation. Sexual differentiation was naturally maintained with the action of estrogens since the initial stages of development.

GMC: male rats that in the intrauterine life were subjected to the action of testosterone up to the fourth day of life when the action of this hormone, produced in the testis, was interrupted in a critical stage of the CNS development until the induction of acute abdominal sepsis.

GMCR: male rats that were subjected to the action of testosterone from intrauterine life until the fourth day post- 
natal when they were suppressed of their testosterone supply for 24 hours. After this period of suppression, exogenous replacement of this hormone was carried out until the 11th day of life, still in its critical period of sexual differentiation. After the $11^{\text {th }}$ day, rats in this group were no longer subjected to the action of testosterone, testicular or exogenous.

GM: male rats with no hormonal manipulation and with natural sexual differentiation with normal testicular testosterone action in the early stages of differentiation and with physiologic serum levels of this hormone at the moment of experimental acute sepsis.

With the percentages observed in this experiment, we can infer that there is an actual higher female resistance to sepsis. However, castrated male responded in a similar way, which may suggest that testosterone can play a decisive role in the immune response of these animals. Observations stemming from the experiment may be explained by the differentiated immune response between males and females, references thereof abounding in the literature. Sexual dimorphism is also present in the immune response. Both humoral and cellular responses are more active in females. In humans, females are more affected by autoimmune disease $^{28}$. In a general way, females present a better cellular and humoral immune response than males; females also have a higher count of immunoglobulins ${ }^{29}$ and a higher and more sustained production of antibodies following immunization and infection ${ }^{30,31}$. Immunoglobulin levels vary between sexes, with some antibodies such as IgG and IgM higher in females in response to antigenic stimulus. CD4 lymphocyte levels are also higher in women ${ }^{32}$. Females also show a higher rejection of alografts, demonstrating a better cell mediated immune response $\mathrm{e}^{33}$. As for the effect of sex on the immune system (IS), regulation of $\mathrm{T}$ and $\mathrm{B}$ cells are the most important. The alteration of cytokine levels is proportional to sexual steroid levels and is the product of immune cells, particularly of the T cell population ${ }^{34}$. Sexual hormones play a central role in this sexual dimorphism of the immune system. The involved mechanisms are complex and not fully known. It could be through direct action on immunocompetent cells as, for example, in the presence of androgen receptors on thymus cell ${ }^{353}$. Another mechanism could be indirect, mediated by the interaction with other immunomodulatory factors such as the thymus hormones, growth hormone and prolactin. A third proposed mechanism would be through the influence of sexual steroids in the levels of glycocorticoids. Given that sexual steroids affect the hypothalamus-pituitary-adrenal (HPA) cortex axis directly, and also influence immunocompetent cells and cytokine production, the total effect of sexual steroids in the glycocorticoid response to stress may derive from all of these actions ${ }^{36}$. Studies show there is an inter-relation between CNS, IS and the hypothalamus-pituitary-adrenal (HPA) cortex axis. In the $70 \mathrm{~s}^{14}$ and later in the $80 \mathrm{~s}$, Besedovsky et $\mathrm{al}^{37}$ demonstrated that classic hormones and the recently-discovered cytokines were functionally involved in the communication between CNS and the IS, referring that the interactions between the IS and the neuroendocrine play an important role in the modulation of the HPA axis in organisms exposed to a immune stimulus.
This axis is susceptible to permanent modifications when manipulated in early stages of development. Shanks et $\mathrm{al}^{38}$ demonstrated that exposure to endotoxins in development critical stages reduces the negative feedback of glycocorticoid on ACTH, increasing the response of the HPA axis to stress. Sex-specific responses in adult animals may be manipulated by administering hormones in the neonatal period, according to what was described by Hiemke et $\mathrm{al}^{39}$. Thus, Del Rey et $\mathrm{al}^{40}$ demonstrated that the administration of IL-1 until the fifth day of life in mice causes permanent alterations to the HPA axis, with a reduction of basal values of corticosterone and increase in regards to ACTH/corticosterone. Konstandoulakis et $\mathrm{al}^{6}$ concluded that the manipulation of sexual steroids in pre and postnatal may cause lasting effects on the immune response, and may also alter existing differences in the immune response between males and females. Castration in adult life was also studied, demonstrating differences in the immune response. Rife et $\mathrm{al}^{41}$ demonstrated that castrated mice in adult life present a better response to antigenic stimulus, an effect which was reduced with the administration of testosterone. Wilson et $\mathrm{al}^{42}$ observed that castration of adult male mice reflect in an important increase in the production of B lymphocytes. Castration of adult male rats cause an increase in the plasmatic levels of ACTH and corticosterone in response to stress, an effect that was reverted with testosterone replacement ${ }^{43}$. Wichmann et $\mathrm{al}^{44}$ studying the immune response of normal and castrated rats in the trauma of soft parts and hemorrhagic shock concluded that male sexual steroids have an immunodepressant effect. He also suggests that androgen blockers might have a potential clinical use. Other effects of castration in adult life are increase of peripheral cell B compartment, increased capacity of selfreactive immunoglobulin production ${ }^{45}$ increasing macrophage fagocytosis capacity ${ }^{46}$. Da Silva et $\mathrm{al}^{47}$ also demonstrated in humans that estradiol levels increased and testosterone inhibited the endogenous response of glycocorticoids following inflammatory stimulus, in a pattern similar to animal studies. The present study carried out an experimental modulation of the immune response of the HPA axis by castrating male rats on the fourth day of life. Thus, this axis was prevented from being completed as in the normal male rats. In normal male rats, the presence of testosterone during this first week of post-natal life, modify the organization of the brain circuitry responsible for modulating the immune response in these animals when reaching adult life. Nowadays, it is established that the immune system and the HPA axis are mutually regulatory and that their interaction may be a determining factor when analyzing stress effects on the immune response. Therefore, an experimentally induced inflammatory process must influence the HPA axis and, as a consequence, modify the immune response. Special attention is being given to the role of early stages of life and the HPA cortex axis in the determination of predisposition and susceptibility to diseases in the long-run ${ }^{48}$. As sexual steroids are, apparently, responsible for regulating this response, it is suggestive that the interruption of this modulation in critical periods of the development may imply in a female-like response for castrated male rats. 
It is already established in the literature ${ }^{49}$ that like other forms of plasticity development, sexual differentiation of the neuronal network for reproductive behavior is characterized by critical periods during which, specific interactions between developing cells and the environment determine future behavior capacities. Critical periods of development, are part of the natural sequence of growth, at each stage of development a choice is made within a limited number of alterations. Once this choice has been made in this period, it is virtually impossible to revert the results. Chromosomal sex of an individual is established when the male sperm contributes with a X or Y chromosome. Genetic sex determines if the bipotential embryonic gonad will differentiate into ovary or testis. The subsequent steps in the differentiation result from the action of hormones. If chromosome $\mathrm{Y}$ is present, testes will develop and their hormonal secretion will result in the development of a male phenotype. The same is not true for the development of the ovaries and the differentiation of females. The removal of gonadal tissue from rabbit fetuses will result in animals with female phenotype, regardless whether they genetically XX or XY. Therefore, the female phenotype can develop in the absence of any gonadal tissue. Testosterone secreted by the testes masculinizes the sexual organs, rudimentary mammal gland and the CNS. In the adult, sexual steroids activate primarily the sexual response. So, the action of gonadal hormones on the mature nervous system is activational and transitory. In our experiment, this type of effect caused by sexual hormones (activational effect) cannot be analyzed, since the experiment castrated newlyborn rats whose brain circuitry of the HPA cortex axis which participate in the modulatory process of the immune system still are not fully established in this stage of development $\left(4^{\text {th }} \text { day post-natal }\right)^{12}$. Therefore, in this experiment we are analyzing the organizational effect that testosterone may cause during one of the critical stages of the CNS development of rats and its consequences to the response of these animals to a septic challenge. In this research, we also applied the Multiple Correspondence Analysis (MCA) with the aim to investigate the occurrence of association among the variables of study subgroups, death after 24 hours, within 24 hours and non-death. The results obtained suggest an association between subgroups GM and GMCR with death within 24 hours. On the other hand, GF indicates a strong association with the occurrence of death after 24 hours. Such results are perfectly in agreement with the data reviewed in the literature, which indicate a better female response to a septic challenge compared to normal males. Subgroups GM and GMCR showed a close relationship between themselves, in a similar way to subgroups GF and GMC. Subgroups that showed a bigger difference between themselves were subgroups GF and GM. Considering that GM and GMCR are subgroups in which the presence of testosterone was permanent (GM) or temporary during a critical development stage (GMCR), the data indicate a relationship between the subgroups of animals with testosterone and death, especially within 24 hours. An association between subgroups GF and GMC was also observed. That is, in the subgroups without testosterone or with testosterone before the end of testosterone critical period of action in the sexual differentiation of the CNS and the immune system. These results are in agreement with literature data on the influence exerted by testosterone on the structuring of several brain circuits involved in the modulation of the immune response in the face of a septic challenge. No reference regarding the use of MCA to evaluate the variables described above was found in the literature. Thus, it is not possible to compare the obtained data with those of other studies employing the same design. It is important to observe that in subgroup GMCR the animals' own testosterone was active only until the fourth day post-natal. After castration, replacement with testosterone propionate was administered from the fifth to the $11^{\text {th }}$ day. After this, there was no testicular testosterone action. Despite this, the animals in this subgroup presented a behavior that was more similar to that of subgroup GM than any other group. This reinforces the importance of testosterone in the critical stages to program the immune response, regardless of testosterone serum levels at the moment of induced acute sepsis. Survival of animals was also analyzed by Kaplan-Meier curve. This curve determines the statistical chance of a given element in the group to be alive after a given time. Thus, in the experiment, the odds for females to be alive after 24 hours were $80 \%$, while in the other groups they were as follows: GMC 50\%; GMCR 20\% and 0\% for GM. This other form of survival verification reinforces the data previously verified by the Kruskal-Wallis test and by MCA. Kaplan-Meier survival curve, analyzed in 24 hours, showed a significant statistical difference when verified by log-rank, in the four subgroup $(p=0,0055)$. Comparative analysis only for the subgroups GF and GM represent a difference still bigger with $p=0,0005$. What would explain this bigger difference among groups without hormone manipulation (GF and GM) is the sum of the sexual steroids actions. The first, linked to the sexual differentiation stage, a moment in which a programming is underway for differentiating male and female responses. The second is linked to the different circulating levels of these steroids at the moment of sepsis. In this case, estrogens in higher levels in females improve immune response to sepsis, while testosterone in males has the opposite effect. No studies were found in the literature that used the methodology of the survival curve to compare these events. Its use in this design of research proved useful for future studies on the sexual dimorphism of the immune response, in particular in the evaluation of acute sepsis with early death. Aspects of physiopathology, related to the dosage of sexual steroids, corticoids, cytokines and lymphocyte count, must be employed to explain the reasons of this dimorphism. Likewise, experiments using immunomodulators, especially sexual steroids (and/or similar compounds) or their blockers, can generate useful information in the study of sepsis treatment. It also brings to light the discussion whether earlier action in terms of immunomodulation with sexual steroids should be taken on the onset of sepsis. Immunohistochemical studies, in particular on the CNS, will determine areas involved in the sexual dimorphism of the immune response. Based on the results, we can suggest that the presence or absence of sexual hormones in male rats during sexual differentiation of the CNS and the IS lead to different immune responses in their adult life when subjected to sepsis. 


\section{Conclusion}

There was a significant difference in the survival rates among subgroups of males and males submitted to castration and experimental sepsis, when analyzed within 24 hours.

\section{Referências}

1. Parrillo JE, Parker MM, Natanson C, Suffredini AF, Danner RL, Cunnion RE, et al. Septic shock in humans. Advances in the understanding of pathogenesis, cardiovascular dysfunction, and therapy. Ann Intern Med. 1990; 113(3):227-42.

2. Brun-Buisson C, Doyon F, Carlet J, Dellamonica P, Gouin F, Lepoutre A, et al. Incidence, risk factors, and outcome of severe sepsis and septic shock in adults. A multicenter prospective study in intensive care units. French ICU Group for Severe Sepsis. J Am Med Assoc. 1995; 274(12):968-74.

3. d 'Acampora AJ. Modelo de sepse experimental em ratos. Estudo clínico e histológico [Doutorado]. São Paulo: Universidade Federal de São Paulo. Escola Paulista de Medicina; 1996.

4. Matte ELA, Tholl CJ, d'Acampora AJ. Avaliação da peritonite bacteriana difusa induzida em ratos Wistar. In: UFSC, editor. IV Seminário Catarinense de Iniciação Científica; 1994; Florianópolis; 1994. p. 424.

5. Parker SJ, Watkins PE. Experimental models of gramnegative sepsis. Br J Surg. 2001; 88(1):22-30.

6. Konstadoulakis MM, Syrigos KN, Baxevanis CN, Syrigou EI, Papamichail M, Peveretos P, et al. Effect of testosterone administration, pre- and postnatally, on the immune system of rats. Horm Metab Res. 1995; 27(6):275-8.

7. Verthelyi D. Sex hormones as immunomodulators in health and disease. Int Immunopharmacol. 2001; 1(6):983-93.

8. Angele MK, Schwacha MG, Ayala A, Chaudry IH. Effect of gender and sex hormones on immune responses following shock. Shock. 2000; 14(2):81-90.

9. Serafim JDM. Efeito castração pós-natal na sepse experimental em ratos [TCC]. Florianópolis: Universiddae Federal de Santa Catarina; 2002.

10. Schroder J, Kahlke V, Staubach KH, Zabel P, Stuber F. Gender differences in human sepsis. Arch Surg. 1998; 133(11):1200-5.

11. Stumpf WE. Estrogen-neurons and estrogen-neuron systems in the periventricular brain. Am J Anat. 1970; 129(2):207-17.

12. Goy RW, Mcewen BS. Sexual differentiation of the Brain. In: Neurosciences Research Program; 1977; Massachusetts: MIT; 1977.p. 81-147.

13. Grossman CJ, Roselle GA. The interrelationship of the HPG-thymic axis and immune system regulation. J Steroid Biochem. 1983; 19(1B):461-7.

14. Besedovsky H, Sorkin E, Felix D, Haas H. Hypothalamic changes during the immune response. Eur J Immunol. 1977; 7(5):323-5.

15. Besedovsky HO, del Rey A. Immune-neuro-endocrine interactions: facts and hypotheses. Endocr Rev. 1996; 17(1):64-102.

16. Dorner G, Staudt J. Structural changes in the preoptic anterior hypothalamic area of the male rat, following neonatal castration and androgen substitution. Neuroendocrinology. 1968; 3(3):136-40.

17. Corbier P, Roffi J, Rhoda J. Female sexual behavior in male rats: effect of hour of castration at birth. Physiol Behav. 1983; 30(4):613-6.

18. Chowen JA, Argente J, Gonzalez-Parra S, Garcia-Segura LM. Differential effects of the neonatal and adult sex steroid environments on the organization and activation of hypothalamic growth hormone- releasing hormone and somatostatin neurons. Endocrinology. 1993; 133(6):2792-802.

19. Madeira MD, Lieberman AR. Sexual dimorphism in the mammalian limbic system. Prog Neurobiol. 1995; 45(4):275-333.

20. Patchev VK, Hayashi S, Orikasa C, Almeida OF. Implications of estrogen-dependent brain organization for gender differences in hypothalamo-pituitary-adrenal regulation. Faseb J. 1995; 9(5):419-23.

21. McEwen BS. Protective and damaging effects of stress mediators: central role of the brain. Prog Brain Res. 2000; 122:25-34.

22. Teplick R, Rubin R. Therapy of sepsis: why have we made such little progress? Crit Care Med. 1999; 27(8):1682-3.

23. Deitch EA. Animal models of sepsis and shock: a review and lessons learned. Shock. 1998; 9(1):1-11.

24. Wichterman KA, Baue AE, Chaudry IH. Sepsis and septic shock - a review of laboratory models and a proposal. J Surg Res. 1980; 29(2):189-201.

25. Ortellado DK, D’Acampora AJ, Souza EJ, Gerente MM. Sobrevida após peritonite por perfuração de víscera oca em ratos wistar. In: $6^{\circ}$ Congresso Brasileiro da Ciência de Animais de Laboratório; 1998; Porto Alegre; 1998. p. 38.

26. Oberholzer A, Keel M, Zellweger R, Steckholzer U, Trentz $\mathrm{O}$, Ertel W. Incidence of septic complications and multiple organ failure in severely injured patients is sex specific. J Trauma. 2000; 48(5):932-7.

27. Yesilova Z, Ozata M, Kocar IH, Turan M, Pekel A, Sengul A, et al. The effects of gonadotropin treatment on the immunological features of male patients with idiopathic hypogonadotropic hypogonadism. J Clin Endocrinol Metab. 2000; 85(1):66-70.

28. Beeson PB. Age and sex associations of 40 autoimmune diseases. Am J Med. 1994; 96(5):457-62.

29. Butterworth M, McClellan B, Allansmith M. Influence of sex in immunoglobulin levels. Nature. 1967; 214(94):1224-5.

30. Ansar AS, Talal N. Sex hormones and autoimmune rheumatic disorders. Scand J Rheumatol. 1989; 18(2):69-76.

31. Brick JE, Wilson DA, Walker SE. Hormonal modulation of responses to thymus-independent and thymusdependent antigens in autoimmune NZB/W mice. J Immunol. 1985; 134(6):3693-8. 
32. Giltay EJ, Fonk JC, von Blomberg BM, Drexhage HA, Schalkwijk C, Gooren LJ. In vivo effects of sex steroids on lymphocyte responsiveness and immunoglobulin levels in humans. J Clin Endocrinol Metab. 2000; 85(4):1648-57.

33. Graff RJ, Lappe MA, Snell GD. The influence of the gonads and adrenal glands on the immune response to skin grafts. Transplantation. 1969; 7(2):105-11.

34. Lahita RG. Gender and the immune system. J Gend Specif Med. 2000; 3(7):19-22.

35. Kovacs WJ, Olsen NJ. Androgen receptors in human thymocytes. J Immunol. 1987; 139(2):490-3.

36. Da Silva JA. Sex hormones, glucocorticoids and autoimmunity: facts and hypotheses. Ann Rheum Dis. 1995; 54(1):6-16.

37. Besedovsky HO, del Rey AE, Sorkin E. Immuneneuroendocrine interactions. J Immunol. 1985; $135(2$ Suppl):750s-4s.

38. Shanks N, Larocque S, Meaney MJ. Neonatal endotoxin exposure alters the development of the hypothalamicpituitary-adrenal axis: early illness and later responsivity to stress. J Neurosci. 1995; 15(1 Pt 1):376-84.

39. Hiemke C, Banger M, Kohsik R, Hundt M, Ghraf R. Actions of sex hormones on the brain. Prog Neuropsychopharmacol Biol Psychiatry. 1992; 16(3):377-88.

40. del Rey A, Furukawa H, Monge-Arditi G, Kabiersch A, Voigt KH, Besedovsky HO. Alterations in the pituitaryadrenal axis of adult mice following neonatal exposure to interleukin-1. Brain Behav Immun. 1996; 10(3):235-48.

41. Rife SU, Marquez MG, Escalante A, Velich T. The effect of testosterone on the immune response. 1. Mechanism of action on antibody-forming cells. Immunol Invest. 1990; 19(3):259-70.
42. Wilson CA, Mrose SA, Thomas DW. Enhanced production of B lymphocytes after castration. Blood. 1995; 85(6):1535-9.

43. Viau V, Meaney MJ. The inhibitory effect of testosterone on hypothalamic-pituitary-adrenal responses to stress is mediated by the medial preoptic area. J Neurosci. 1996; 16(5):1866-76.

44. Wichmann MW, Ayala A, Chaudry IH. Male sex steroids are responsible for depressing macrophage immune function after trauma-hemorrhage. Am J Physiol. 1997; 273(4 Pt 1):C1335-40.

45. Viselli SM, Stanziale S, Shults K, Kovacs WJ, Olsen NJ. Castration alters peripheral immune function in normal male mice. Immunology. 1995; 84(2):337-42.

46. De Azevedo RB, Rosa LF, Lacava ZG, Curi R. Gonadectomy impairs lymphocyte proliferation and macrophage function in male and female rats. Correlation with key enzyme activities of glucose and glutamine metabolism. Cell Biochem Funct. 1997; 15(4):293-8.

47. Da Silva JA. Sex hormones and glucocorticoids: interactions with the immune system. Ann N Y Acad Sci. 1999;876:102-17.

48. Shanks N, Lightman SL. The maternal-neonatal neuroimmune interface: are there long-term implications for inflammatory or stress-related disease? J Clin Invest. 2001; 108(11):1567-73.

49. Kelly DD. Sexual Differentiation of the Nervous System. In: Kelly DD, editor. Principles of Neural Science. Third ed. Norwalk: Prentice Hall; 1997. p. 959-73.

\section{Correspondence:}

Armando José d'Acampora

Condomínio San Diego, casa 9

88024-420 - Florianópolis - SC - Brazil

Phone: (55 48)9961-0316

e-mail: dacampora@gmail.com
Conflict of interest: none Financial source: none

Received: August 06, 2006

Review: September 16, 2006

Accepted: October 22, 2006

\section{How to cite this article:}

Bernhardt JA, d'Acampora AJ, Tramonte R, Serafim JD. Effect of post-natal castration on sepsis mortality in rats. Acta Cir Bras. [serial on the Internet] 2007 Jan-Feb;22(1). Available from URL: http://www.scielo.br/acb. 